\title{
PENGARUH KUALITAS PELAYANAN TERHADAP KEPUASAN NASABAH KREDIT PADA PT. BPR JKT PARIAMAN
}

\author{
Riki Handika, Febsri Susanti \\ Sekolah Tinggi Ilmu Ekonomi "KBP" \\ febsrisusanti@akbpstie.ac.id \\ ricky.handika88@yahoo.com
}

\begin{abstract}
The purpose of this study was to analyze the effect of reliability, responsiveness, assurance, empathy and tangibles to satisfaction of customer credit at PT. BPR JKT Pariaman. The population in this study are all customers of credit at PT. BPR JKT Pariaman. The sampling technique is random sampling, while the number of samples used for the analysis is 86 clients. The data analysis technique used to test the hypothesis is multiple linear regression. In this study, there are two independent variables, namely reliability, responsiveness, assurance, empathy and tangibles. Variables that have a significant influence on customer satisfaction credit at PT. BPR JKT Pariaman is responsiveness, assurance, and empathy. While the value of correlation coefficient obtained in this study amounted to 0.970, this shows that there is a very strong relationship between reliability, responsiveness, assurance, empathy and tangibles to satisfaction of customer credit at PT. BPR JKT Pariaman. For the coefficient of determination in this study was found to be 0.937 or equal to $93.7 \%$. The results showed that of the credit customer satisfaction at PT. BPR JKT Pariaman which can be explained by reliability, responsiveness, assurance, empathy and tangibles amounting to 93.7\%, while 6.3\% thought to be explained by other factors not examined in this study, such as trust, customer value perception, and the company's image. Based on the test results of multiple linear regression analysis, it was found that the variable reliability, responsiveness, assurance, empathy and physical evidence of a positive effect on customer satisfaction credit at PT. BPR JKT Pariaman. This study provides practical recommendations for the management of PT. BPR JKT Pariaman to continue to improve responsiveness, assurance, and empathy in the future. This is due to responsiveness, assurance, and empathy have a significant impact on customer satisfaction credit at PT. BPR JKT Pariaman.
\end{abstract}

Keywords: Reliability, Responsiveness, Assurance, Empathy, Physical Evidence and Satisfaction 


\section{Latar Belakang Masalah}

Bank Perkreditan Rakyat (BPR) merupakan satu perusahaan yang bergerak dalam bidang jasa. Bank Perkreditan Rakyat diharapkan dapat membantu masyarakat dalam mengatasi masalah keuangan dengan cara memberikan kredit berupa uang pinjaman, menghimpun dan menyalurkan dana masyarakat melalui kegiatan usaha perkreditan yang dibutuhkan oleh para calon nasabah dalam rangka meningkatkan modal usaha sehingga tercipta kesejahteraan hidup yang baik.

PT. BPR JKT Pariaman sebagai perusahaan jasa perbankan, tidak akan mungkin menghindar dari realita persaingan industri jasa perbankan yang semakin meningkat. Sehubungan dengan konteks kualitas pelayanan dalam mempertahankan nasabah, PT. BPR JKT Pariaman mengembangkan produk kredit. Melayani fasilitas kredit untuk kredit modal kerja, kredit investasi, kredit konsumtif dan kredit kepemilikan kendaraan (PT. BPR JKT Pariaman, 2016).

Selain itu, masalah yang dihadapi dalam pelaksanaan kegiatan perkreditan selama ini oleh PT. BPR JKT Pariaman adalah banyak kredit yang tidak dikembalikan sesuai dengan jadwal yang telah ditentukan. Dengan kata lain telah terjadi kredit macet. Adanya kredit macet ini menimbulkan kerugian pada bank yang disebabkan tidak berputarnya modal yang dimiliki bank. Dalam jangka panjang kredit macet yang terjadi di bank selain dapat merugikan pihak bank. Mengingat kemacetan kredit yang terjadi pada bank mempunyai dampak yang sangat buruk bagi bank, maka seharusnya dilakukan penanganan kredit macet oleh bank. Berikut ini adalah gambaran mengenai data tahun 2013 hingga tahun 2015 nasabah kredit PT. BPR JKT Pariaman dapat dilihat pada tabel 1 sebagai berikut:

Tabel 1

Perkembangan Jumlah Nasabah Kredit Pada PT. BPR JKT Pariaman Tahun 2013 sampai dengan Tahun 2015

\begin{tabular}{|c|l|c|c|c|}
\hline \multirow{2}{*}{ No } & \multirow{2}{*}{ Fasilitas Kredit } & \multicolumn{3}{|c|}{ Tahun (Orang) } \\
\cline { 3 - 5 } & & 2013 & 2014 & 2015 \\
\hline 1 & Kredit Modal Kerja & 68 & 53 & 62 \\
\hline 2 & Kredit Investasi & 43 & 34 & 38 \\
\hline 3 & Kredit Konsumtif & 178 & 242 & 226 \\
\hline 4 & Kredit Kepemilikan Kendaraan & 265 & 302 & 289 \\
\hline \multicolumn{2}{|r|}{ Total } & 554 & 631 & 615 \\
\hline
\end{tabular}

Sumber: PT. BPR JKT Pariaman, 2016

Berdasarkan data jumlah nasabah kredit yang diperoleh dari PT. BPR JKT Pariaman dari tahun 2013 sampai tahun 2015 menunjukkan adanya fluktuasi dari tahun ke tahunnya. Dimana pada tahun 2013 jumlah nasabah kredit sebanyak 554 orang, dan meningkat pada tahun 2014 menjadi 631 orang, namun pada tahun 2015 jumlah nasabah kredit menurun menjadi 615 orang. Hal ini sesuai dengan kenyataannya bahwa masih banyaknya keluhan yang disampaikan oleh nasabah terhadap pelayanan yang diberikan oleh PT. BPR JKT Pariaman yang dapat dilihat pada Tabel 2 sebagai berikut: 
Tabel 2

Jumlah Keluhan Nasabah Kredit Pada PT. BPR JKT Pariaman Tahun 2013 sampai dengan Tahun 2015

\begin{tabular}{|c|l|c|c|c|}
\hline \multirow{2}{*}{ No } & \multirow{2}{*}{ Fasilitas Kredit } & \multicolumn{3}{|c|}{ Tahun (Orang) } \\
\cline { 3 - 5 } & & 2013 & 2014 & 2015 \\
\hline 1 & Kredit Modal Kerja & 38 & 43 & 52 \\
\hline 2 & Kredit Investasi & 27 & 31 & 38 \\
\hline 3 & Kredit Konsumtif & 19 & 26 & 29 \\
\hline 4 & Kredit Kepemilikan Kendaraan & 42 & 47 & 58 \\
\hline \multicolumn{2}{|c|}{ Total } & 126 & 147 & 177 \\
\hline
\end{tabular}

Sumber: PT. BPR JKT Pariaman, 2016

Dari tabel 2 dapat diketahui bahwa keluhan dari nasabah kredit PT. BPR JKT Pariaman dari tahun 2013 sampai dengan tahun 2015 mengalami peningkatan. Banyaknya keluhan tersebut dipengaruhi dalam hal pelayanan yang diterima. Seperti kurangnya keramahan karyawan, dikarenakan perusahan tidak penerapkan standar minimal pelayanan misalkan senyum, sapa dan salam. Serta karyawan tidak pernah diberikan pelatihan mengenai komunikasi yang baik dengan nasabah. Kurang luasnya ruang tunggu yang disediakan, Keluhan nasabah sering kali ditanggapi oleh karyawan terlalu lama, dikarenakan sedikitnya jumlah karyawan yang ada dalam customer service sehingga banyak dari nasabah yang terlalu lama mengantri.

Kepuasan nasabah terlahir karena diberikannya kualitas pelayanan yang baik yang mencangkup keandalan, daya tanggap, jaminan, empati, dan wujud (Tjiptono, 2011: 346-347). Kelima unsur kulitas pelayanan ini, paling tidak akan memberikan kepuasan nasabah bila Bank selalu melayani melebihi harapan nasabahnaya. Berkaitan dengan hal tersebut, dengan adanya nasabah yang mengeluh terhadap pelayanan PT. BPR JKT Pariaman menunjukkan adanya penurunan kualitas pelayanan yang diberikan oleh penyedia jasa, yaitu PT. BPR JKT Pariaman sehingga berdampak pada penurunan kepuasan nasabah kredit.

Dalam hal ini, PT. BPR JKT Pariaman menerapkan serangkaian langkah strategis yang akan dilakukan untuk meningkatkan kepuasan nasabahnya yaitu dengan pemberian kualitas pelayanan yang maksimal, sehingga berujung pada peningkatan kepuasan nasabah dan pencapaian tujuan perusahaan. Berdasarkan fenomena tersebut, maka penulis tertarik untuk melakukan penelitian empirik yang dituangkan kedalam penelitian dengan judul: "Pengaruh Kualitas Pelayanan Terhadap Kepuasan Nasabah Kredit Pada PT. BPR JKT Pariaman."

Rumusan Masalah

1. Apakah keandalan berpengaruh terhadap kepuasan nasabah kredit pada PT. BPR JKT Pariaman?

2. Apakah daya tanggap berpengaruh terhadap kepuasan nasabah kredit pada PT. BPR JKT Pariaman?

3. Apakah jaminan berpengaruh terhadap kepuasan nasabah kredit pada PT. BPR JKT Pariaman?

4. Apakah empati berpengaruh terhadap kepuasan nasabah kredit pada PT. BPR JKT Pariaman? 
5. Apakah wujud berpengaruh terhadap kepuasan nasabah kredit pada PT. BPR JKT Pariaman?

Tujuan Penelitian

1. Untuk mengetahui dan menganalisis pengaruh keandalan terhadap kepuasan nasabah kredit pada PT. BPR JKT Pariaman.

2. Untuk mengetahui dan menganalisis pengaruh daya tanggap terhadap kepuasan nasabah kredit pada PT. BPR JKT Pariaman.

3. Untuk mengetahui dan menganalisis pengaruh jaminan terhadap kepuasan nasabah kredit pada PT. BPR JKT Pariaman.

4. Untuk mengetahui dan menganalisis pengaruh empati terhadap kepuasan nasabah kredit pada PT. BPR JKT Pariaman.

5. Untuk mengetahui dan menganalisis pengaruh wujud terhadap kepuasan nasabah kredit pada PT. BPR JKT Pariaman.

\section{TINJAUAN LITERATUR}

\section{Pemasaran}

\section{Pengertian Manajemen Pemasaran}

Banyak ahli yang telah memberikan definisi atas pemasaran. Pemasaran yang diberikan sering berbeda antara ahliyang satu dengan ahli yang lain. Perbedaan ini disebabkan karena adanya perbedaan para ahli tersebut dalam memandang dan meminjau pemasaran, dalam kegiatan pemasaran ini aktivitas pertukaran merupakan hal sentral. Pertukaran merupakan kegiatan pemasaran dimana seseorang berusaha menawarkan sejumlah barang atau jasa dengan sejumlah nilai keberbagai macam kelompok sosial untuk memenuhi kebutuhannya.

Pemasaran Menurut Kotler dan Keller (2009:5), pemasaran adalah mengidentifikasi dan memenuhi kebutuhan manusia dan sosial. Dari teori diatas terdapat dua aspek yaitu, pertama pemasar berusaha untuk memuaskan kebutuhan dan keinginan pasar sasaran dan kedua, pemasar meliputi studi tentang proses pertukaran dimana terdapat dua pihak yang menstransfer sumber moneter dan sumber daya lainnya dari para konsumen. Sedangkan menurut Tjiptono (2008:5), pemasaran bertujuan untuk menarik pembeli dalam mengkonsumsi produk yang ditawarkan. Oleh karena itu pemasaran memainkan peranan penting dalam pengembangkan strategi.

\section{Kepuasan}

\section{Pengertian Kepuasan}

Kepuasan pelanggan menjadi sangat bernilai bagi perusahaan, sehingga tidak heran selalu ada slogan bahwa pelanggan adalah raja, yang perlu dilayani dengan sebaik-baiknya. Kepuasan konsumen memiliki makna yang beragam. Kepuasan tidak selamanya diukur dengan uang, tetapi lebih didasarkan pada pemenuhan perasaan tentang apa yang dibutuhkan seseorang.

Mowen dan Minor (2002:89) menyatakan bahwa kepuasan konsumen adalah keseluruhan sikap yang ditunjukkan konsumen atas barang atau jasa setelah mereka memperoleh dan menggunakannya. Ini merupakan penilaian evaluatif pasca pemilihan yang disebabkan oleh seleksi pembelian khusus dan pengalaman menggunakan atau mengkonsumsi barang atau jasa tersebut. 
Menurut Kotler dan Keller (2009:14) kepuasan mencerminkan penilaian seseorang tentang kinerja produk anggapannya atau hasil kaitannya dalam ekspektasi. Jika kinerja produk tersebut tidak memenuhi ekspektasi, pelanggan tersebut tidak puas dan kecewa. Jika kinerja produk sesuai dengan ekspektasi, pelanggan tersebut puas. Jika kinerja produk melebihi ekspektasi, pelanggan tersebut senang.

\section{Indikator Kepuasan Pelanggan}

Dalam realita bisnis, konsumen dapat mengevaluasi berbagai kombinasi atribut-atribut positif sebuah produk/jasa sebagai penentu tingkat kepuasan pelanggan, sebagai berikut: (Hasan, 2013:99)

1. Serviceability

2. Accessibility

3. Communication

4. Competence

5. Courtesy

6. Reliability

7. Security

8. Tangibles

9. Understanding customer

\section{Kualitas Pelayanan}

\section{Pengertian Kualitas Pelayanan}

Kualitas jasa harus dimulai dari kebutuhan pelanggan dan berakhir dengan kepuasan pelanggan serta persepsi positif terhadap kualitas jasa (Tjiptono dan Gregorious, 2011:180). Lovelock dan Wright (2007:96) menyatakan bahwa, "Kualitas jasa adalah evaluasi kognitif jangka panjang pelanggan terhadap penyerahan jasa suatu perusahaan."

Menurut Lupiyoadi dan Hamdani (2009:181), "Kualitas jasa dapat didefenisikan sebagai seberapa jauh perbedaan antara kenyataan dan harapan pelanggan atas layanan yang mereka terima." Selanjutnya kualitas pelayanan dibangun atas adanya perbandingan dua faktor utama, yaitu persepsi pelanggan atas layanan yang nyata mereka terima (perceived service) dengan layanan yang sesungguhnya diharapkan (expected service). Jika kenyataan nya lebih dari yang diharapkan maka layanan dapat dikatakan berkualitas, dan sebaliknya.

\section{Dimensi dan Indikator Kualitas Pelayanan}

Menurut Parasuraman dkk dalam Kotler dan Keller (2009:52), terdapat lima determinan kualitas jasa berdasarkan urutan pentingnya, yaitu: "Keandalan, Responsivitas, Jaminan, Empati, dan Wujud.”

1. Keandalan, kemampuan untuk melaksanakan jasa yang dijanjikan dengan andal dan akurat.

2. Responsivitas, kesediaan membantu pelanggan dan memberikan layanan tepat waktu.

3. Jaminan, pengetahuan dan kesopanan karyawan serta kemampuan mereka untuk menunjukkan kepercayaan dan keyakinan.

4. Empati, kondisi memperhatikan dan memberikan perhatian pribadi kepada pelanggan.

5. Wujud, penampilan fasilitas fisik, perlatan, personel, dan bahan komunikasi. 
Selanjutnya, Parasuraman, dkk dalam Kotler dan Keller (2009:52) menguraikan tentang atribut SERVQUAL (kualitas pelayanan) sebagai berikut:

1. Keandalan

a. Perusahaan tepat dalam memenuhi janji

b. Karyawan mampu memecahkan masalah nasabah

c. Perusahaan memberikan layanan secara tepat sejak awal

d. Perusahaan menyediakan layanan sesuai waktu yang dijanjikan

2. Responsivitas

a. Selalu memberitahu pelanggan tentang kapan layanan akan dilaksanakan.

b. Layanan tepat waktu bagi pelanggan

c. Kesediaan membantu pelanggan

d. Kesiapan untuk merespons permintaan pelanggan

3. Jaminan

a. Karyawan yang menanamkan keyakinan pada pelanggan

b. Membuat pelanggan merasa aman dalam transaksi mereka

c. Karyawan yang selalu sopan

d. Perusahaan tidak pernah memiliki masalah dalam segi apapun

4. Empati

a. Memberikan perhatian kepada pelanggan

b. Karyawan yang menghadapi pelanggan dengan cara yang penuh perhatian

c. Mengutamakan kepentingan terbaik pelanggan\

d. Jam bisnis yang nyaman

5. Wujud

a. Peralatan modern

b. Fasilitas yang tampak menarik secara visuall

c. Karyawan yang memiliki penampilan rapi dan profesional

d. Bahan yang berhubungan dengan jasa mempunyai daya tarik visual

\section{Hipotesis}

Hipotesis 1 Diduga keandalan berpengaruh signifikan terhadap kepuasan nasabah kredit pada PT. BPR JKT Pariaman.

Hipotesis 2 Diduga daya tanggap berpengaruh signifikan terhadap kepuasan nasabah kredit pada PT. BPR JKT Pariaman.

Hipotesis 3 Diduga jaminan berpengaruh signifikan terhadap kepuasan nasabah kredit pada PT. BPR JKT Pariaman.

Hipotesis 4 Diduga empati berpengaruh signifikan terhadap kepuasan nasabah kredit pada PT. BPR JKT Pariaman.

Hipotesis 5 Diduga wujud berpengaruh signifikan terhadap kepuasan nasabah kredit pada PT. BPR JKT Pariaman.

\section{METODE PENELITIAN}

\section{Populasi}

Di dalam penelitian ini yang menjadi populasi adalah seluruh nasabah kredit PT. BPR JKT Pariaman berjumlah 615 orang.

\section{Teknik Pengambilan Sampel}

Menentukan sampel dengan menggunakan rumus Slovin (Umar, 2013:78), sebagai berikut: 


$$
n=\frac{N}{1+N\left(e^{2}\right)}
$$

Di mana:

$\mathrm{N}=$ Besar Populasi

$\mathrm{n}=$ Besar Sampel

$\mathrm{e}^{2}=$ Taraf kesalahan yang diinginkan diambil $10 \%$.

Persentase kelonggaran pengambilan sampel pada penelitian ini ditetapkan sebesar $10 \%(0,1)$. Berdasarkan rumus Slovin di atas, dengan populasi $(\mathrm{N})$ sebanyak 615 orang dan taraf kesalahan (e) sebesar 10\%, maka jumlah sampel adalah:

$$
\begin{aligned}
& \mathrm{n}=615 /\left\{1+615(0,1)^{2}\right\} \\
& \mathrm{n}=615 /\{1+615(0,01)\} \\
& \mathrm{n}=615 /\{1+6,15\} \\
& \mathrm{n}=615 / 7,15 \\
& \mathrm{n}=86
\end{aligned}
$$

Melalui perhitungan dengan menggunakan rumus slovin diatas maka jumlah responden sebagai sampel dalam penelitian ini adalah sebanyak 86 orang. Dalam penelitian ini teknik penarikan sampel yang digunakan adalah metode random sampling, yaitu pengambilan sampel secara acak.

\section{Teknik Analisis Data}

\section{Analisis Regresi Linier Berganda}

Uji regresi linear berganda merupakan teknik statistik yang digunakan untuk menguji pengaruh beberapa variabel bebas terhadap variabel terikat (Sekaran, 2006:299). Persamaan regresi linier berganda adalah:

Di mana:

$$
Y=\alpha+\beta_{1} X_{1}+\beta_{2} X_{2}+\beta_{3} X_{3}+\beta_{4} X_{4}+\beta_{5} X_{5}
$$

$$
\begin{array}{ll}
\text { Y } & =\text { Kepuasan } \\
\alpha & =\text { Konstanta } \\
\beta_{1}, \beta_{2}, \beta_{3}, \beta_{4}, \beta_{5} & =\text { Koefisien Regresi } \\
X_{1} & =\text { Keandalan } \\
X_{2} & =\text { Daya Tanggap } \\
X_{3} & =\text { Jaminan } \\
X_{4} & =\text { Emapti } \\
X_{5} & =\text { Wujud }
\end{array}
$$

\section{Pengujian Hipotesis}

\section{Uji T}

Uji t dilakukan untuk menguji apakah variabel bebas berppengaruh signifikan terhadap variabel terikat secara parsial atau indvidu. Kriteria pengujian:

1. Jika t hitung $>\mathrm{t}$ tabel, maka $\mathrm{H}_{0}$ ditolak dan $\mathrm{H}_{1}$ diterima.

2. Jika t hitung $<\mathrm{t}$ tabel, maka $\mathrm{H}_{0}$ diterima dan $\mathrm{H}_{1}$ ditolak.

3. Tingkat kepercayaan $\alpha$ untuk pengujian hipotesis adalah $95 \%$ atau $\alpha=0,05$

\section{HASIL PENELITIAN DAN PEMBAHASAN \\ Hasil Analisis Regresi Berganda}

Data yang di peroleh dalam penelitian ini akan dianalisis dengan mengguna-kan metode statistik untuk menguji hipotesis dan variabel yang di 
gunakan. Data tersebut dianalisis dengan menggunakan SPSS (Statistical Program for Science) versi 16.0. Uji regresi linear berganda merupakan teknik statistik yang digunakan untuk menguji pengaruh beberapa variabel bebas terhadap variabel terikat. Hasil analisis regresi linier berganda dapat diringkas pada Tabel berikut ini:

Tabel 3

Ringkasan Hasil Analisis Regresi Linier Berganda

\begin{tabular}{|l|l|c|}
\hline Variabel Terikat & Konstanta danVariabel Bebas & Koefisien Regresi \\
\hline \multirow{5}{*}{ Kepuasan $(\mathrm{Y})$} & Konstanta $(\mathrm{a})$ & 0,305 \\
\cline { 2 - 3 } & Keandalan $\left(\mathrm{X}_{1}\right)$ & 0,034 \\
\cline { 2 - 3 } & Daya Tanggap $\left(\mathrm{X}_{2}\right)$ & 0,385 \\
\cline { 2 - 3 } & Jaminan $\left(\mathrm{X}_{3}\right)$ & 0,432 \\
\cline { 2 - 3 } & Empati $\left(\mathrm{X}_{4}\right)$ & 0,079 \\
\cline { 2 - 3 } & Wujud $\left(\mathrm{X}_{5}\right)$ & 0,004 \\
\hline
\end{tabular}

Sumber: Olahan Data Primer 2016.

Berdasarkan hasil analisis regresi linier berganda yang disajikan pada Tabel diatas, berikut ini dapat dikemukakan persamaan regresi linier berganda:

$$
\mathrm{Y}=0,305+0,034 \mathrm{X}_{1}+0,385 \mathrm{X}_{2}+0,432 \mathrm{X}_{3}+0,079 \mathrm{X}_{4}+0,004 \mathrm{X}_{5}
$$

Koefisisen regresi masing-masing variabel penelitian dapat diartikan sebagai berikut:

1. Nilai konstanta sebesar 0,305 berarti tanpa adanya pengaruh dari variabel bebas maka nilai variabel terikat hanya sebesar 0,305. Hal ini berarti bahwa apabila variabel bebas nilainya konstan (keandalan, daya tanggap, jaminan, empati, dan wujud), maka nilai variabel kepuasan hanya sebesar 0,305.

2. Besaran koefisien regresi variabel keandalan bernilai positif bermakna jika variabel keandalan mengalami kenaikan maka kepuasan akan mengalami peningkatan. Koefisien bernilai positif artinya terjadi hubungan positif antara keandalan dengan kepuasan, semakin baik keandalan maka kepuasan akan semakin tinggi. Besaran koefisien regresi variabel keandalan adalah 0,034 satuan. Hal ini bermakna bahwa jika terjadi peningkatan keandalan sebesar satu satuan dengan asumsi variabel daya tanggap, jaminan, empati, dan wujud tetap, maka akan meningkatkan kepuasan sebesar 0,034 satuan.

3. Besaran koefisien regresi variabel daya tanggap bernilai positif bermakna jika variabel daya tanggap mengalami kenaikan maka kepuasan akan mengalami peningkatan. Koefisien bernilai positif artinya terjadi hubungan positif antara daya tanggap dengan kepuasan, semakin baik daya tanggap maka kepuasan akan semakin tinggi. Besaran koefisien regresi variabel daya tanggap adalah 0,385 satuan. Hal ini bermakna bahwa jika terjadi peningkatan daya tanggap sebesar satu satuan dengan asumsi variabel keandalan, jaminan, empati, dan wujud tetap, maka akan meningkatkan kepuasan sebesar 0,385 satuan.

4. Besaran koefisien regresi variabel jaminan bernilai positif bermakna jika variabel jaminan mengalami kenaikan maka kepuasan akan mengalami peningkatan. Koefisien bernilai positif artinya terjadi hubungan positif antara jaminan dengan kepuasan, semakin baik keandalan maka kepuasan akan semakin tinggi. Besaran koefisien regresi variabel jaminan adalah 0,432 
satuan. Hal ini bermakna bahwa jika terjadi peningkatan jaminan sebesar satu satuan dengan asumsi variabel keandalan, daya tanggap, empati, dan wujud tetap, maka akan meningkatkan kepuasan sebesar 0,432 satuan.

5. Besaran koefisien regresi variabel empati bernilai positif bermakna jika variabel empati mengalami kenaikan maka kepuasan akan mengalami peningkatan. Koefisien bernilai positif artinya terjadi hubungan positif antara empati dengan kepuasan, semakin baik empati maka kepuasan akan semakin tinggi. Besaran koefisien regresi variabel empati adalah 0,079 satuan. Hal ini bermakna bahwa jika terjadi peningkatan empati sebesar satu satuan dengan asumsi variabel keandalan, daya tanggap, jaminan, dan wujud tetap, maka akan meningkatkan kepuasan sebesar 0,079 satuan.

6. Besaran koefisien regresi variabel wujud bernilai positif bermakna jika variabel wujud mengalami kenaikan maka kepuasan akan mengalami peningkatan. Koefisien bernilai positif artinya terjadi hubungan positif antara wujud dengan kepuasan, semakin baik keandalan maka kepuasan akan semakin tinggi. Besaran koefisien regresi variabel wujud adalah 0,004 satuan. Hal ini bermakna bahwa jika terjadi peningkatan wujud sebesar satu satuan dengan asumsi variabel keandalan, daya tanggap, jaminan, dan empati, maka akan meningkatkan kepuasan sebesar 0,004 satuan.

\section{HASIL DAN PEMBAHASAN}

Untuk melakukan uji hipotesis secara parsial, dapat dilihat dari ringkasan hasil analisis regresi yang disajikan pada Tabel 4 sebagai berikut:

\section{Tabel 4}

Hasil Uji T Statistik

\begin{tabular}{|c|l|c|c|l|}
\hline $\begin{array}{c}\text { Variabel } \\
\text { Terikat }\end{array}$ & \multicolumn{1}{|c|}{$\begin{array}{c}\text { Konstanta dan } \\
\text { Variabel Bebas }\end{array}$} & $\begin{array}{c}\text { Koefisien } \\
\text { Regresi }\end{array}$ & Sig. & Kesimpulan \\
\hline \multirow{4}{*}{$\begin{array}{c}\text { Kepuasan } \\
\text { Nasabah } \\
(\mathrm{Y})\end{array}$} & Konstanta $(\mathrm{a})$ & 0,305 & 0,011 & - \\
\cline { 2 - 5 } & Keandalan $\left(\mathrm{X}_{1}\right)$ & 0,034 & 0,324 & H1 Ditolak \\
\cline { 2 - 5 } & Daya Tanggap $\left(\mathrm{X}_{2}\right)$ & 0,385 & 0,000 & H2 Diterima \\
\cline { 2 - 5 } & Jaminan $\left(\mathrm{X}_{3}\right)$ & 0,432 & 0,000 & H3 Diterima \\
\cline { 2 - 5 } & Empati $\left(\mathrm{X}_{4}\right)$ & 0,079 & 0,009 & H4 Diterima \\
\cline { 2 - 5 } & Wujud $\left(\mathrm{X}_{5}\right)$ & 0,004 & 0,905 & H5 Ditolak \\
\cline { 2 - 5 } & $\mathrm{F}$ & 253,877 & 0,000 & - \\
\hline
\end{tabular}

Sumber: Olahan Data Primer 2016.

\section{Pengaruh Keandalan Terhadap Kepuasan Nasabah}

Uji t digunakan untuk mengetahui pengaruh variabel independen terhadap variabel dependen secara individu atau parsial. Hipotesis pertama bahwa keandalan memiliki nilai signifikansi sebesar 0,324, nilai signifikan tersebut lebih besar dari alpha 0,05 . Hal ini dapat diartikan bahwa keandalan tidak berpengaruh terhadap kepuasan nasabah kredit pada PT. BPR JKT Pariaman. Dengan demikian keandalan tidak menentukan kepuasan nasabah kredit pada PT. BPR JKT Pariaman.

Adapun alasan yang dapat disampaikan mengapa variabel keandalan tidak berpengaruh terhadap kepuasan kredit pada PT. BPR JKT Pariaman, karena keandalan dalam penelitian ini merupakan ketepatan perusahaan dalam memenuhi 
janji nasabah, karyawan mampu memecahkan masalah nasabah, perusahaan memberikan layanan secara tepat sejak awal, perusahaan menyediakan layanan sesuai waktu yang dijanjikan. Hal ini sesuai dengan yang dinyatakan oleh Kotler dan Keller (2009:52).

Dalam hal ini dimana keandalan yang diberikan oleh PT. BPR JKT Pariaman relatif sama dengan keandalan yang ditberikan oleh Bank konvensional. Dengan demikian, menyediakan jasa sesuai yang dijanjikan, keandalan dalam penanganan masalah layanan nasabah, melaksanakan jasa dengan benar pada saat pertama, menyediakan jasa pada waktu yang dijanjikan, dan perusahaan menyediakan layanan sesuai waktu yang dijanjikan, tidaklah memiliki perbedaan yang berarti antara PT. BPR JKT Pariaman dengan Bank konvensional lainnya, sehingga kondisi tersebut tidaklah penting menjelaskan kepuasan nasabah.

Hasil penelitian ini tidak sejalan dengan penelitian yang dilakukan oleh Tran, dkk (2015) tentang service quality effects on customer satisfaction in banking industry. Penelitian ini menguji hubungan antara lima faktor dalam model kualitas pelayanan dan kepuasan pelanggan dengan layanan deposit VCBs. Menurut hasil penelitian, lima faktor yang positif terkait dengan kepuasan pelanggan. Namun, kehandalan yang hanya memiliki dukungan parsial, menunjukkan kebutuhan untuk meningkatkan keandalan pada deposit VCBs menjadi lebih kompetitif di pasar. Munjiati Munawaroh (2005) dengan judul penelitian Analisis Pengaruh Kualitas Jasa Terhadap Kepuasan Pada Industri Pendidikan di Yogyakarta. Dimana hasil dari penelitian ini adalah terdapat pengaruh antara kualitas layanan yang terdiri dari berwujud, keandalan dan jaminan terhadap kepuasan.

\section{Pengaruh Daya Tanggap Terhadap Kepuasan Nasabah}

Uji t digunakan untuk mengetahui pengaruh variabel independen terhadap variabel dependen secara individu atau parsial. Hipotesis kedua bahwa daya tanggap memiliki nilai signifikansi sebesar 0,000 , nilai signifikan tersebut lebih kecil dari alpha 0,05. Hal ini dapat diartikan bahwa daya tanggap signifikan berpengaruh terhadap kepuasan nasabah kredit pada PT. BPR JKT Pariaman.

Hasil penelitian ini sejalan dengan penelitian yang dilakukan oleh $\mathrm{Ni}$ Nyoman Yuliarmi dan Putu Riyasa (2007) dengan judul Analisis Faktor-Faktor yang Mempengaruhi Kepuasan Pelanggan Terhadap Pelayanan PDAM Kota Denpasar. Hasil penelitian ini menunjukkan bahwa variable kualitas pelayanan yang terdiri dari berwujud, empati, ketanggapan dan jaminan berpengaruh positif terhadap kepuasan. Penelitian yang dilakukan oleh Munjiati Munawaroh (2005) dengan judul penelitian Analisis Pengaruh Kualitas Jasa Terhadap Kepuasan Pada Industri Pendidikan di Yogyakarta. Dimana hasil dari penelitian ini adalah terdapat pengaruh antara kualitas layanan yang terdiri dari berwujud, keandalan dan jaminan terhadap kepuasan.

\section{Pengaruh Jaminan Terhadap Kepuasan Nasabah}

Uji t digunakan untuk mengetahui pengaruh variabel independen terhadap variabel dependen secara individu atau parsial. Hipotesis ketiga bahwa jaminan memiliki nilai signifikansi sebesar 0,000, nilai signifikan tersebut lebih kecil dari alpha 0,05. Hal ini dapat diartikan bahwa jaminan berpengaruh signifikan terhadap kepuasan nasabah kredit pada PT. BPR JKT Pariaman. 
Hasil penelitian ini sejalan dengan penelitian yang dilakukan oleh $\mathrm{Ni}$ Nyoman Yuliarmi dan Putu Riyasa (2007) dengan judul Analisis Faktor-Faktor yang Mempengaruhi Kepuasan Pelanggan Terhadap Pelayanan PDAM Kota Denpasar. Hasil penelitian ini menunjukkan bahwa variable kualitas pelayanan yang terdiri dari berwujud, empati, ketanggapan dan jaminan berpengaruh positif terhadap kepuasan.Penelitian yang dilakukan oleh Munjiati Munawaroh (2005) dengan judul penelitian Analisis Pengaruh Kualitas Jasa Terhadap Kepuasan Pada Industri Pendidikan di Yogyakarta. Dimana hasil dari penelitian ini adalah terdapat pengaruh antara kualitas layanan yang terdiri dari berwujud, keandalan dan jaminan terhadap kepuasan.

\section{Pengaruh Empati Terhadap Kepuasan Nasabah}

Uji t digunakan untuk mengetahui pengaruh variabel independen terhadap variabel dependen secara individu atau parsial. Hipotesis keempat bahwa empati memiliki nilai signifikansi sebesar 0,009, nilai signifikan tersebut lebih besar dari alpha 0,05 . Hal ini dapat diartikan bahwa wujud berpengaruh signifikan terhadap kepuasan nasabah kredit pada PT. BPR JKT Pariaman.

Hasil penelitian ini sejalan dengan penelitian yang dilakukan oleh $\mathrm{Ni}$ Nyoman Yuliarmi dan Putu Riyasa (2007) dengan judul Analisis Faktor-Faktor yang Mempengaruhi Kepuasan Pelanggan Terhadap Pelayanan PDAM Kota Denpasar. Hasil penelitian ini menunjukkan bahwa variable kualitas pelayanan yang terdiri dari berwujud, empati, ketanggapan dan jaminan berpengaruh positif terhadap kepuasan.Penelitian yang dilakukan oleh Munjiati Munawaroh (2005) dengan judul penelitian Analisis Pengaruh Kualitas Jasa Terhadap Kepuasan Pada Industri Pendidikan di Yogyakarta. Dimana hasil dari penelitian ini adalah terdapat pengaruh antara kualitas layanan yang terdiri dari berwujud, keandalan dan jaminan terhadap kepuasan.

\section{Pengaruh Wujud Terhadap Kepuasan Nasabah}

Uji t digunakan untuk mengetahui pengaruh variabel independen terhadap variabel dependen secara individu atau parsial. Hipotesis kelima bahwa wujud memiliki nilai signifikansi sebesar 0,905, nilai signifikan tersebut lebih besar dari alpha 0,05. Hal ini dapat diartikan bahwa keandalan tidak berpengaruh terhadap kepuasan nasabah kredit pada PT. BPR JKT Pariaman.

Adapun alasan yang dapat disampaikan mengapa variabel wujud/bukti fisik tidak berpengaruh terhadap kepuasan nasabah kredit pada PT. BPR JKT Pariaman, karena wujud/bukti fisik dalam penelitian ini merupakan Peralatan modern, fasilitas yang tampak menarik secara visual, karyawan yang memiliki penampilan rapi dan profesional, dan bahan yang berhubungan dengan jasa mempunyai daya tarik visual. Hasil ini sesuai dengan yang dinyatakan oleh Kotler dan Keller (2009:52).

Kondisi ini, mungkin saja disebabkan karena nasabah sudah sangat kritis terhadap masalah-masalah layanan bank, khususnya fasilitas yang tersedia pada Bank. Sehingga untuk memutuskan puas, nasabah harus benar-benar merasakan manfaat dari pelayanan yang diberikan terlebih dahulu. Di samping itu, sifat dari layanan bank yang intangibles di mana seorang nasabah memutuskan puas memerlukan waktu yang cukup untuk menikmati atau mengkonsumsi layanan 
yang menurut bank sudah ditingkatkan kualitasnya. Jika seorang nasabah sudah menikmati dan merasakan maka nasabah akan puas pada bank tersebut.

Nasabah hanya akan berurusan dengan bank berdasarkan kepada tingkat kebutuhannya semata sehingga proses mencari layanan bank, khususnya dengan fasilitas terbaik masih terus dilakukan. Namun PT. BPR JKT Pariaman tetap berusaha dan berupaya memberikan dan berusaha meningkatkan layanan, khususnya pada fasilitas layanan terbaik guna menarik simpati nasabah agar tetap puas. Perusahaan telah melakukan berbagai inovasi bagi peningkatan layanan, seperti menyediakan peralatan modern, fasilitas yang tampak menarik secara visual, karyawan yang memiliki penampilan rapi dan profesional, dan bahan yang berhubungan dengan jasa mempunyai daya tarik visual.

Hasil penelitian ini tidak sejalan dengan penelitian yang dilakukan oleh $\mathrm{Ni}$ Nyoman Yuliarmi dan Putu Riyasa (2007) dengan judul Analisis Faktor-Faktor yang Mempengaruhi Kepuasan Pelanggan Terhadap Pelayanan PDAM Kota Denpasar. Hasil penelitian ini menunjukkan bahwa variable kualitas pelayanan yang terdiri dari berwujud, empati, ketanggapan dan jaminan berpengaruh positif terhadap kepuasan. Penelitian yang dilakukan oleh Munjiati Munawaroh (2005) dengan judul penelitian Analisis Pengaruh Kualitas Jasa Terhadap Kepuasan Pada Industri Pendidikan di Yogyakarta. Dimana hasil dari penelitian ini adalah terdapat pengaruh antara kualitas layanan yang terdiri dari berwujud, keandalan dan jaminan terhadap kepuasan.

\section{KESIMPULAN DAN SARAN}

\section{Kesimpulan}

1. Keandalan tidak berpengaruh terhadap kepuasan nasabah kredit pada PT. BPR JKT Pariaman.

2. Daya tanggap berpengaruh signifikan terhadap kepuasan nasabah kredit pada PT. BPR JKT Pariaman.

3. Jaminan berpengaruh signifikan terhadap kepuasan nasabah kredit pada PT. BPR JKT Pariaman.

4. Empati berpengaruh signifikan terhadap kepuasan nasabah kredit pada PT. BPR JKT Pariaman.

5. Wujud tidak berpengaruh terhadap kepuasan nasabah kredit pada PT. BPR JKT Pariaman.

6. Dari hasil olahan data, diketahui bahwa dari pengujian Koefisien Determinasi terlihat nilai koefisen determinasi adalah sebesar 0,937 atau sama dengan 93,7\%. Hasil tersebut memperlihatkan bahwa dari kepuasan nasabah kredit pada PT. BPR JKT Pariaman yang dapat dijelaskan oleh keandalan, daya tanggap, jaminan, empati, dan daya tanggap sebesar 93,7\%, sedangkan sisanya $6,3 \%$ diduga dijelaskan oleh faktor-faktor lain yang tidak diteliti dalam penelitian ini, seperti kepercayaan, persepsi nilai nasabah, dan citra perusahaan.

7. Berdasarkan hasil pengolahan data diperoleh angka $\mathrm{R}$ (Koefisien Korelasi) sebesar 0,970, hal ini menunjukkan bahwa terjadi hubungan yang sangat kuat antara keandalan, daya tanggap, jaminan, empati, dan daya tanggap terhadap kepuasan nasabah kredit pada PT. BPR JKT Pariaman. 
8. Dari analisis regresi linier berganda, ditemukan bahwa keandalan, daya tanggap, jaminan, empati dan wujud berpengaruh positif terhadap kepuasan nasabah kredit pada PT. BPR JKT Pariaman.

\section{Saran}

1. Penelitian ini hanya menganilisis dimensi kualitas pelayanan serta masih adanya variabel lain diluar model penelitian yang mempengaruhi terbentuknya kepuasan nasabah kredit yang tidak digunakan dalam penelitian ini.

2. Sulitnya bagi peneliti untuk menentukan sampel yang benar dapat mewakili seluruh populasi sehingga mempengaruhi hasil yang ditemukan didalam penelitian ini.

3. Dalam upaya meningkatkan kepuasan nasabah di masa yang akan datang, maka disarankan kepada pihak manajemen PT. BPR JKT Pariaman untuk terus berupaya meningkatkan daya tanggap, jaminan, dan empati. Hal ini disebabkan daya tanggap, jaminan, dan empati memiliki pengaruh yang berarti dalam meningkatkan kepuasan nasabah kredit pada PT. BPR JKT Pariaman.

\section{DAFTAR PUSTAKA}

Arikunto, Suharsimi. 2010. Prosedur Penelitian: Suatu Pendekatan Praktek. Edisi Revisi V. Rineka Cipta: Jakarta

Aziz, N. (2019). Analisis Pengaruh Kualitas Produk, Harga, Promosi Terhadap Keputusan Pembelian Air Minum Dalam Kemasan (AMDK) Merek Aicos $\begin{array}{llll}\text { Produksi } & \text { Pt. } & \text { Bumi } & \text { Sarimas }\end{array}$ https://doi.org/10.17605/OSF.IO/8XKYB

Aziz, N. (2019). Pengaruh Kualitas Layanan Terhadap Kepuasan Nasabah SMS Banking Pada Bank Nagari Cabang Pembantu RSUP DR M Djamil Padang. https://doi.org/10.17605/OSF.IO/S3JVG

Fernandes, Y. D., \& Marlius, D. (2018). Peranan Customer Service Dalam Meningkatkan Pelayanan Kepada Nasabah Pada PT. Bank Pembangunan Daerah Sumatera Barat Cabang Utama Padang. https://doi.org/10.31227/osf.io/wrh3p

Hasan, Ali. 2013. Marketing dan Kasus-Kasus Pilihan. Jakarta: CAPS.

Khoiru Rusydi dan Fathoni.2008. Pengaruh Kualitas Pelayanan terhadap Kepuasan Wajib Pajak Kendaraan Bermotor di Kota Batu. Jurnal Aplikasi Manajemen. Volume 9 Nomor 3 Mei 2011.

Kotler, Philip dan Keller, Kevine.,Lane. 2009. Manajemen Pemasaran.Jilid 2.Edisi 13. Erlangga: Jakarta. 
Kotler, Philip dan Armstrong, Garry, 2008. Prinsip-prinsip Pemasaran, Jilid 1, Erlangga, Jakarta.

Lovelock, Christopher, H, and Wright, Lauren K. 2007.Manajemen Pemasaran Jasa. Indeks: Jakarta

Lupiyoadi, Rambat dan Hamdani, Ahmad. 2009. Manajemen Pemasaran Jasa. Penerbit Salemba Empat: Jakarta

Marlius, D. (2018). Loyalitas Nasabah Bank Nagari Syariah Cabang Bukittinggi Dilihat Dari Kualitas Pelayanan. Jurnal Pundi. Volume 1. No. 3. Hal.1222. https://doi.org/10.31575/jp.v1i3.60

Marlius, D. (2018). Pengaruh Dimensi Kualitas Pelayanan Website Akademik Terhadap Kepuasan Mahasiswa Pada STIE “KBP”. Jurnal Ipteks Terapan. $\begin{array}{lllll}\text { Volume } & 12 . & \text { No. } & \text { Hal. } & \text { 116-128. }\end{array}$ http://doi.org/10.22216/jit.2018.v12i2.633

Marlius, D. (2017). Keputusan Pembelian Berdasarkan Faktor Psikologis Dan Bauran Pemasaran Pada PT. Intercom Mobilindo Padang. Jurnal Pundi. Volume 1. No. 1. Hal. 57-66. https://doi.org/10.31575/jp.v1i1.9

Marlius, D. (2016). Pengaruh Bauran Pemasaran Jasa Terhadap Minat Nasabah Dalam Menabung Pada Bank Nagari Cabang Muaralabuh. https://doi.org/10.31227/osf.io/vdqgx

Mayliza, R. (2019). Pengaruh Citra Perusahaan (Corporate Image) Dan Penanganan Keluhan (Complaint Handling) Terhadap Loyalitas Pelanggan (Loyality) Natasha Skin Care Di Kota Padang. https://doi.org/10.17605/OSF.IO/DF9XJ

Mowen, J.C dan Minor, M. 2002. Perilaku Konsumen. Jilid 2, Edisi Kelima. Erlangga: Jakarta

Munjiati Munawaroh.2000."Analisis Pengaruh Kualitas Jasa Terhadap Kepuasan Pada Industri Pendidikan Di Yogyakarta.” Jurnal Siasat Bisnis, Edisi No. 5 Vol. 2, Th. 2000 ISSN:0853-7665

Ni Nyoman Yuliarmi dan Putu Riyasa.2007."Analisis Faktor-Faktor yang Mempengaruhi Kepuasan Pelanggan Terhadap Pelayanan PDAM Kota Denpasar." ISSN1410-4628 BULETIN STUDI EKONOMI Volume 12 Nomor 1 Tahun 2007

Safitri, R. N., \& Marlius, D. (2017). Penerapan E-Banking Dalam Meningkatkan Jasa Dan Layanan Perbankan Di PT. Bank Rakyat Indonesia Cabang Padang. https://doi.org/10.31227/osf.io/gkv8t 
Peter, Paul. J and Olson,C. Jerry.2000. Consumer Behavior: Perilaku Konsumen danStrategi Pemasaran. Jilid 1. Edisi 4, Erlangga: Jakarta

Putra, A. M., \& Fernos, J. (2019). Pelaksanaan Pelayanan Prima Terhadap Kepercayaan Nasabah Di PT. Bank Perkreditan Rakyat Jorong Kampung Tangah Pariaman. https://doi.org/10.31227/osf.io/c3fy4

Sekaran, Uma. 2006. Research Methods For Business, Edisi Keempat. Salemba Empat: Jakarta

Sugiyono. 2013. Metode Penelitian Manajemen, Cetakan Pertama, Alfabeta:Bandung

Tiza, M. F., \& Susanti, F. (2019). Pengaruh Kualitas Pelayanan Terhadap Kepuasan Pelanggan, Studi kasus pada perusahaan JNE Cabang Padang. https://doi.org/10.31227/osf.io/hx87m

Tjiptono, Fandy dan Gregorius Chandra,2011, Service, Quality, Satisfaction, ANDI: Yogyakarta

Tjiptono, Fandy dkk. 2003. Total Quality Management, Yogyakarta : Andi

Tjiptono, Fandy,2008. Strategi Pemasaran, ANDI: Yogyakarta

Tran Van Quyet, Nguyen Quang Vinh dan Taikoo Chang.2015. Service Quality Effects on Customer Satisfaction in Banking Industry. Journal: International Journal of $u$ - and e-Service, Science and Technology Vol.8, No. 8 (2015), pp.199-ISSN: 2005-4246

Umar, Husein2013.Metode Penelitian Untuk Skripsi dan Tesis Bisnis. PT. Raja Grafindo: Jakarta

Yuvendri, R., \& Susanto, R. (2019). Meningkatkan Mutu Pelayanan Dalam Usaha Menghimpun Dana Masyarakat (Tabungan) Pada PT. Bank Perkreditan Rakyat Prima Mulia Anugrah Cabang Padang. https://doi.org/10.31219/osf.io/6prcd 